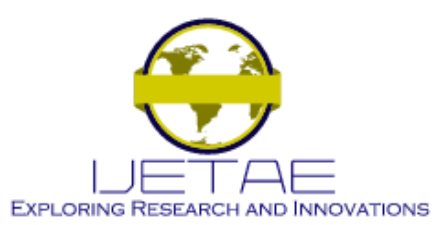

International Journal of Emerging Technology and Advanced Engineering

Website: www.ijetae.com (ISSN 2250-2459, ISO 9001:2008 Certified Journal, Volume 11, Issue 03, March 2021)

Manuscript Received: 04 Feb 2021, Revised: 18 March 2021, Accepted: 24 March 2021 CrossRefDOOI: 10.46338/ijetae0321_02

\title{
Convergence Study on the use of Electrolyzed Water Device with CNT Cathode in Health Field
}

\author{
Doo Hee Han \\ Industrial Technology Convergence Research Institute, Chungwoon University, 113, Sukgol-ro, Michuhol-gu, Incheon, \\ R. O. Korea, 22100
}

\begin{abstract}
An electrolytic water sterilization device was developed that employs CNT (carbon nano tube) as a cathode. CNT plastic composite material is pulverized with a waterdispersible acrylic anionic resin added with castor oil and a dispersion, polypropylene resin mixed with CNT, and thermoplastic elastomer to make pellets. This CNT composite material is a metal-free electric conductor with excellent chemical resistance and surface electrical resistance of $1 \Omega / \square$ or less. When this electrolytic water sterilizer was used as cleaning water for dental treatment and sink cleaning water, it was eco-friendly and showed excellent removal rate. This device can effectively remove pesticides from fruits, etc. and remove bacteria by washing pork. In addition, the water in the swimming pool can be sterilized and purified without using chemicals. In this case, environmental conservation and economic costs can be reduced by not generating wastewater that causes environmental pollution.
\end{abstract}

Keywords-Carbon nano tube, Electrolyzed water, Heaalth, Dentist, Sterilization

\section{INTRODUCTION}

Recently, there have been reports of contaminated oral washing water used in dentistry [1]. Usually, sterilized water is used when performing surgery in a hospital. Especially, when implanting at the dentist, tissue is cut to penetrate into the bone, so it should not be infected with bacteria. As a result of measuring the water quality of the water sprayed on, it was found that the pollution was severe. Table I shows this, all but one is serious.

TABLE I

DENTAL TREATMENT WATER BACTERIA TEST RESULTS

\begin{tabular}{|c|c|}
\hline Area & Number of colonies(CFU/ml) \\
\hline A & 95 \\
\hline B & 690 \\
\hline C & 900 \\
\hline D & 1200 \\
\hline E & 7800 \\
\hline F & 11000 \\
\hline
\end{tabular}

The water used in dentistry is tap water, and it is supposed to go through a water purification device. Treatment water is supplied through pipes and water pipes of about $10 \mathrm{~m}$, which are easily contaminated. In addition, hand washing is strongly required for the spread of COVID19 over a long period of time, and it can be much more effective if water with excellent sterilization ability is used.

Hydrogen water, which is electrolyzed water by water electrolysis equipment, has been studied in various fields [2-3], and that hydrogen water is good for health has been studied academically [4-15].

\section{Sterillzation WASHING SySTEM USING ELECTROLYSIS}

\section{A. Electrolytic sterilization water manufacturing device}

Interest in generating methods and devices for sterilizing and disinfecting water is increasing, and sterilizing and washing water can be used for sterilizing and washing bedding, furniture, various electronic products, toys, laundry and bathrooms not only in the kitchen but also in the home. It can also be used for sterilization cleaning of medical devices.

\section{B. Text Font of Entire Document}

\subsection{Electrolysis of water}

Electrolysis is when an artificial current is applied to water, which has a stable structure, to cause a forced oxidation/reduction reaction.

(-Electrode: basic) $2 \mathrm{H}_{2} \mathrm{O}+2 \mathrm{e} \rightarrow \mathrm{H}_{2}(\mathrm{~g})+2 \mathrm{OH}^{-}$(aq)

(+ electrode: acid) $2 \mathrm{H}_{2} \mathrm{O} \rightarrow \mathrm{O}_{2}(\mathrm{~g})+4 \mathrm{H}^{+}(\mathrm{aq})+4 \mathrm{e}$

When electricity is applied to salt water, sodium hypochlorite $(\mathrm{NaOCl})$, hypochlorous acid $(\mathrm{HOCl})$, and sodium hydroxide $(\mathrm{NaOH})$ are produced. It is mainly used as a disinfectant disinfectant. These metal materials are expensive and unstable, require electrode reversal after 15 minutes of operation, and have unstable problems such as self-heating and current rise. 


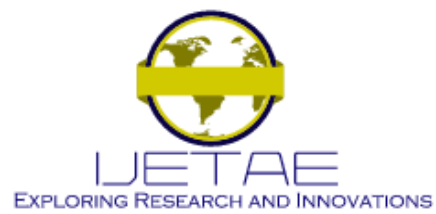

International Journal of Emerging Technology and Advanced Engineering Website: www.ijetae.com (ISSN 2250-2459, ISO 9001:2008 Certified Journal, Volume 11, Issue 03, March 2021)

Electrocatalysts manufactured using carbon nanotubes (CNTs) have excellent far-infrared emission and electrical conductivity, and have features of chemical resistance, moisture resistance, and cold resistance. CNT is difficult to oxidize because its ionization tendency is smaller than that of gold $(\mathrm{Au})$. In general, platinum has a greater tendency to ionize than gold.

\section{Text Font of Entire Document}

\subsection{CNT cathode}

Electrocatalysts mainly used for electrolysis are metals, and platinum groups that do not oxidize well and emit electrons are used. Among them, the expensive materials include platinum $(\mathrm{Pt})$, iridium (Ir), and ruthenium $(\mathrm{Ru})$, and the medium price includes titanium (Ti)-based Pt, Ir, and Ru coated, and the low-cost material is titanium.

CNT is known to have a tensile strength of 100 times that of steel, an electrical conductivity of 1000 times of a copper wire, and a thermal conductivity of $6000 \mathrm{~W} / \mathrm{mK}$, but the specific surface area due to the nanostructure (diameter of 1 to several tens of $\mathrm{nm}$ ) is large and the apparent density is 0.02 to 0.05 Since it is about $\mathrm{g} / \mathrm{cc}$, it was difficult to add more than a certain amount of CNT when compounding with a polymer material. In order to increase the dispersibility of CNT, an oil type CNT dispersant is sometimes used. In this case, the oil used as a dispersant in a continuous high temperature environment of $60^{\circ} \mathrm{C}$ or higher during product molding will escape to the product surface and weaken the adhesion between CNT particles. , Increase the electrical resistance. As a way to avoid this, CNT plastic composite material is made by mixing waterdispersible acrylic-based anion resin and distilled water with urethane properties prepared by adding castor oil to make an acrylic-based anion resin dispersion, and sprayed on CNT to mix CNT and water-dispersible acrylic-based anion resin. Through a process of controlling moisture, a mixture of CNT and water-dispersible acrylic anionic resin is extruded into pellets. This CNT pellet is again compounded with a polypropylene resin and a thermoplastic elastomer to form a pellet. This CNT composite material is a metal-free electrical conductor with excellent chemical resistance and a surface electrical resistance of $1 \Omega / \square$ or less. Fig. 1 shows a structure in which the positive and negative plates are combined.

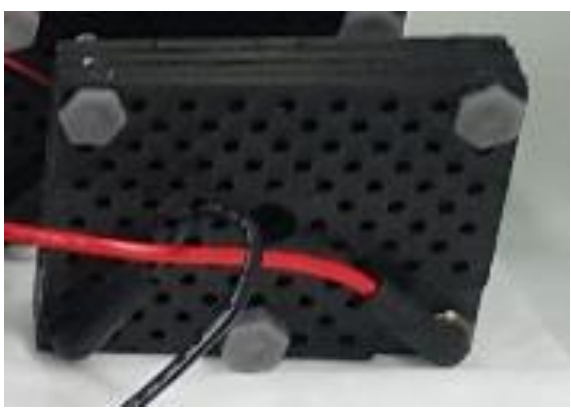

Fig. 1. Combined structure of assembled anode and cathode.

The surface of the metal electrode is damaged by the oxidation-reduction reaction during the electrolysis process, thereby reducing the efficiency. It is also expensive using platinum and the like. On the other hand, the use of CNT-based plastic composites increases the surface area for reaction and is inexpensive. Table II compares the properties of metal electrodes and CNT electrodes.

TABLE II

COMPARISON OF CNT ELECTRODE AND METAL ELECTRODE.

\begin{tabular}{|c|c|c|}
\hline Division & CNT electrode & Metal electrode \\
\hline Electriysis & non diaphragm & non diaphragm \\
\hline $\begin{array}{l}\text { Electrode } \\
\text { catalyst }\end{array}$ & $\mathrm{CNT}$ & Pt, Ir, Ru coated $\mathrm{Ti}(5 \mu \mathrm{m})$ \\
\hline Electrolyte & self catalyzed role & electrolyte needed \\
\hline Property & $\begin{array}{l}\text { - Bipolar-oxidation, } \\
\text { reduction (electron } \\
\text { emission and } \\
\text { migration possible) } \\
\text { - Nonchemical } \\
\text { characteristic } \\
\text { - Current density } \\
(1,000 \text { times } \\
\text { compared with } \\
\text { copper) } \\
\text { - Self-catalyzed role } \\
\text { in distilled water } \\
\text { - Minimize to H2O } \\
\text { clusters } \\
\text { - Maximize the } \\
\text { specific surface area }\end{array}$ & $\begin{array}{l}\text {-Platinum catalyst } \\
\text { - High precious metals } \\
\text { - Low safety when using } \\
\text { basic }(\mathrm{NaCl})(-) \text { poles } \\
\text { - very expensive } \\
\text { - Iridium-coated catalyst } \\
\text { on titanium electrode plate } \\
\text { - Maximizing oxygen } \\
\text { chlorine production } \\
\text { - Strengthen corrosion } \\
\text { resistance } \\
\text { - Minimize pollution when } \\
\text { using }(+) \text { pole }\end{array}$ \\
\hline
\end{tabular}




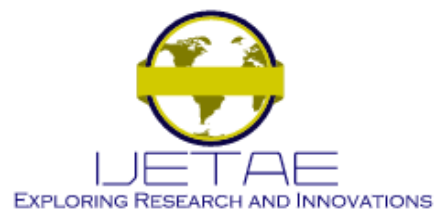

International Journal of Emerging Technology and Advanced Engineering

Website: www.ijetae.com (ISSN 2250-2459, ISO 9001:2008 Certified Journal, Volume 11, Issue 03, March 2021)

CNC electrodes have several advantages compared to general metal electrodes, and Table III shows the performance of sterilizing water generated by the device.

TABLE III

Performance test.

\begin{tabular}{|c|c|c|c|}
\hline Test & Contents & $\begin{array}{l}\text { Inspection } \\
\text { standard }\end{array}$ & Measures \\
\hline \multirow{7}{*}{$\begin{array}{l}\text { Bacterici } \\
\text { dal } \\
\text { power }\end{array}$} & $\begin{array}{l}\text { Escherichia } \\
\text { coli }\end{array}$ & $13000 \mathrm{CFU} / \mathrm{mL}$ & $\begin{array}{l}\text { Removal } \\
\text { rate> }>99.9 \%\end{array}$ \\
\hline & $\begin{array}{l}\text { Staphylococ } \\
\text { cus aureus. }\end{array}$ & $10000 \mathrm{CFU} / \mathrm{mL}$ & $\begin{array}{l}\text { Removal } \\
\text { rate>99.9\% }\end{array}$ \\
\hline & Salmonella & $12000 \mathrm{CFU} / \mathrm{mL}$ & $\begin{array}{l}\text { Removal } \\
\text { rate>99.9\% }\end{array}$ \\
\hline & $\begin{array}{l}\text { Pseudomon } \\
\text { as } \\
\text { geruginesa }\end{array}$ & $15000 \mathrm{CFU} / \mathrm{mL}$ & $\begin{array}{l}\text { Removal } \\
\text { rate>99.9\% }\end{array}$ \\
\hline & $\begin{array}{l}\text { Staphylococ } \\
\text { cus aureus. }\end{array}$ & $10000 \mathrm{CFU} / \mathrm{mL}$ & $\begin{array}{l}\text { Removal } \\
\text { rate>99.9\% }\end{array}$ \\
\hline & Legionella & $600000 \mathrm{CFU} / \mathrm{mL}$ & $\begin{array}{l}\text { Removal } \\
\text { rate>99.9\% }\end{array}$ \\
\hline & $\begin{array}{l}\text { Vibrio } \\
\text { bacteria }\end{array}$ & $500000 \mathrm{CFU} / \mathrm{mL}$ & $\begin{array}{l}\text { Removal } \\
\text { rate> }>99.9 \%\end{array}$ \\
\hline \multirow{3}{*}{$\begin{array}{l}\text { Pesticide } \\
\text { removal }\end{array}$} & Diazinon & $0.0596 \mathrm{mg} / \ell$ & $0.00 / \ell$ \\
\hline & $\begin{array}{l}\text { Phenyirathi } \\
\text { sne. }\end{array}$ & $0.1169 \mathrm{mg} / \ell$ & $0.00 / \ell$ \\
\hline & Byration & $0.1742 \mathrm{mg} / \ell$ & $0.00 / \ell$ \\
\hline
\end{tabular}

\section{ELECTROLYZED WATER SYSTEM USING CNT ELECTRODE}

\section{A. Prototype production}

An electrolytic water device was fabricated by combining a DC power supply, a platinum-plated titanium anode plate, and a CNT cathode plate. Fig. 2 is an electrolytic water device that can be easily used on a laboratory scale and shows an experiment to wash 5-yearold ginseng. I was able to clean it without using any chemicals. As the demand for ginseng has recently increased, hydroponic cultivation with rapid growth has been implemented. As a result of using hydrogen water for hydroponic cultivation, no pesticides occurred and growth was rapid. Fig. 3 shows an electrolyzed water generator capable of producing 100 tons of electrolyzed water per day. This equipment can be used in large-scale sterilization facilities such as laver factories and swimming pools.

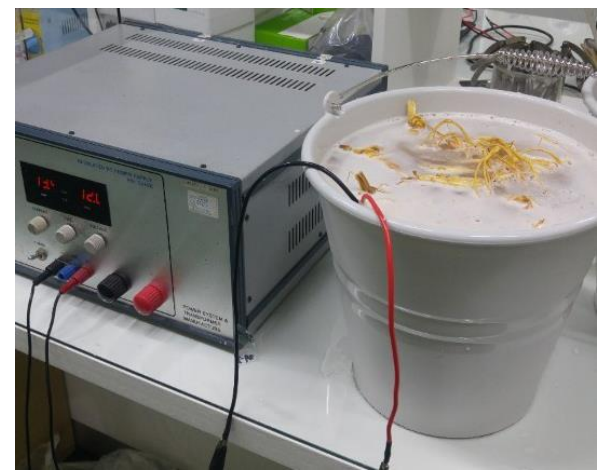

Fig. 2. Electrolyzed water device for easy use on a laboratory scale.

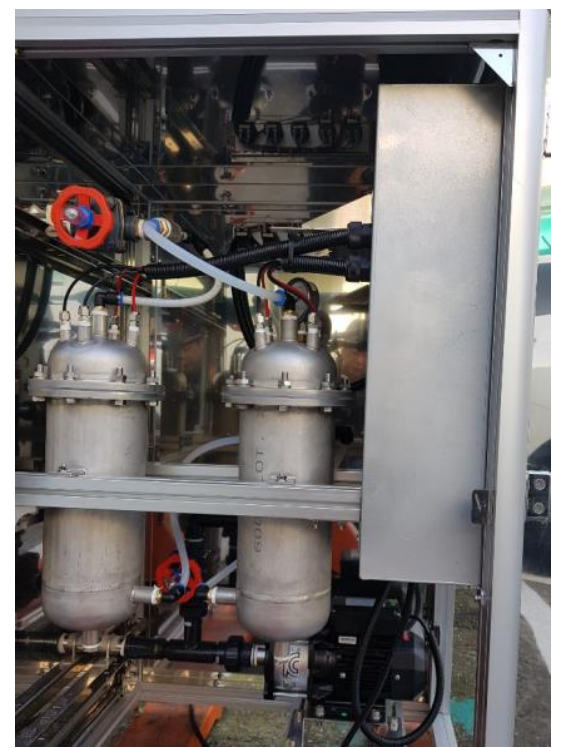

Fig. 3. Electrolyzed water generator using $\mathrm{CNC}$ electrode.

\section{B. Document3.2 Dental medical use}

A lot of bacteria are detected in the dental mouthwash. Most of the time, water pipes are washed and a special sterilization device is attached or a filter is used to sterilize and manage, but it is necessary to use eco-friendly sterilization water to prevent infection, protect patients and medical staff, and become a hospital that is visited a lot. Hypochlorous acid generated in the process of electrolysis of tap water has been recognized by the US FDA as a nontoxic substance and is harmless to the human body. Japan's Ministry of Health, Labor and Welfare also recognized hypochlorous acid as a food disinfectant, a disinfectant for processing fresh fish, and a specific pesticide control. 


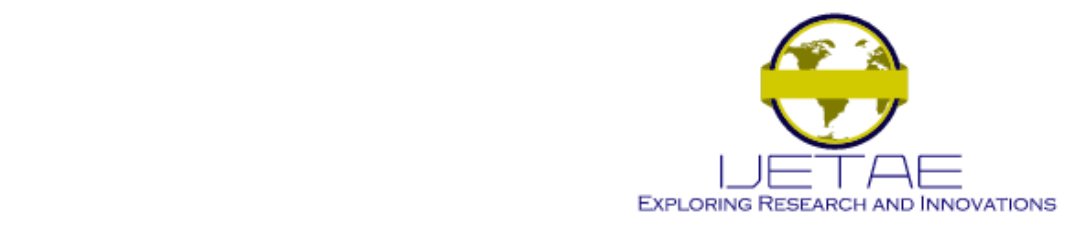

International Journal of Emerging Technology and Advanced Engineering Website: www.ijetae.com (ISSN 2250-2459, ISO 9001:2008 Certified Journal, Volume 11, Issue 03, March 2021)

The crown of a dental unit can be a significant threat to patients with weakened immune systems or to dentists. The American Dental Society (ADA) and the American Centers for Disease Control and Prevention (CDC) recommend the following:

1) The water quality of water used for non-surgical treatment must meet the appropriate criteria for treatment $(\leq 200 \quad \mathrm{CFU} / \mathrm{mL})$ and washing $(\leq 500$ $\mathrm{CFU} / \mathrm{mL}$, water quality suitable for human consumption).

2) During surgery, disinfected water from disinfected equipment should be used [16].

In Korea, there is no standard for the number of bacteria in dental oral water, but the Ministry of Environment regulates the number of bacteria in drinking water not to exceed $100 \mathrm{CFU} / \mathrm{ml}$ [17]. Fig. 4. Shows an water pipe of dental unit.

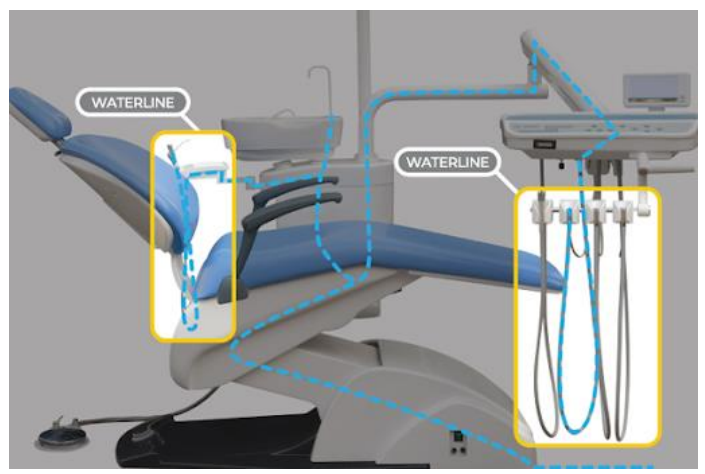

Fig. 4. Water pipe of dental unit.

This hypochlorous acid water can be used as dental oral washing water, and now it is not necessary to clean the water pipe using a regular chemical disinfectant, and the treatment effect can be increased with eco-friendly sterilizing water while preventing infection.

It is very excellent in sterilizing and washing organic matter, so it is optimal as an endoscope cleaner.

When electrolyzed water was used in general dentistry, general bacteria and E. coli present in the mouth of the dental unit chair were investigated. Table IV shows general bacteria and E. coli present in the crown of the dental unit chair when electrolyzed water is used in general dentistry.
Table IV

When Electrolyzed Water Is Used In General Dentistry, General Bacteria And E. Coli Present In The Mouth Of The Dental Unit Chair.

\begin{tabular}{|c|c|c|c|}
\hline \multirow{2}{*}{$\begin{array}{c}\text { Sampl } \\
\text { e } \\
\text { numbe } \\
\mathbf{r}\end{array}$} & \multirow[b]{2}{*}{ Sampling site } & \multicolumn{2}{|c|}{ Culture results } \\
\hline & & $\begin{array}{c}\text { Common } \\
\text { bacteria }\end{array}$ & Coli \\
\hline 1 & $\begin{array}{l}\text { Conservation } \\
\text { department \#1 }\end{array}$ & ND & ND \\
\hline 2 & $\begin{array}{c}\text { Conservation } \\
\text { department \#2 }\end{array}$ & ND & ND \\
\hline 3 & $\begin{array}{c}\text { Conservation } \\
\text { department \#3 }\end{array}$ & ND & ND \\
\hline 4 & $\begin{array}{c}\text { Conservation } \\
\text { department \#26 }\end{array}$ & ND & ND \\
\hline 5 & Periodontal \#4 & ND & ND \\
\hline 6 & Periodontal \#4 & ND & ND \\
\hline 7 & Periodontal \#11 & ND & ND \\
\hline 8 & Periodontal \#12 & ND & ND \\
\hline 9 & Prosthesis \#6 & ND & ND \\
\hline 10 & Prosthesis \#7 & ND & ND \\
\hline 11 & Prosthesis \#8 & ND & ND \\
\hline 12 & Prosthesis \#9 & ND & ND \\
\hline
\end{tabular}

C. Use of sink wash water

Hand washing is the number one priority in preventing infection in the era of Corona 19, and hospital scrub sinks should be washed well for at least 30 seconds. If you use an electrolytic water generator that generates hypochlorous acid, it is made into a powerful eco-friendly sterilizing water hypochlorous acid water $(\mathrm{HOCl})$ without adding any chemicals to the existing water. It can be installed to maximize the sterilization effect. In addition, it is very effective if it is installed in an entrance or toilet where there are frequent visits, and used for hand washing and gargle water. In particular, hospitals, schools, factories, kindergartens, hotels, catering facilities, public institutions, and other multi-use facilities with high risk of infection, and patients, medical staff, staff, and visitors can be protected as much as possible. The advantages of the electrolytic water generator that can be used as washing water are summarized as follows. 


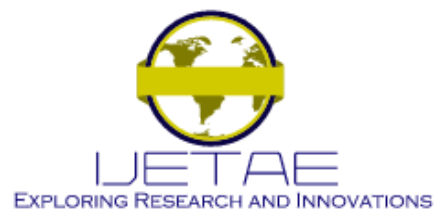

\section{International Journal of Emerging Technology and Advanced Engineering Website: www.ijetae.com (ISSN 2250-2459, ISO 9001:2008 Certified Journal, Volume 11, Issue 03, March 2021)}

1. Excellent sterilization effect and no chlorine odor.

2. It is sterilized water suitable for drinking standards without using any chemicals.

3. It is possible to control the sterilization ability by adjusting the hardness of hypochlorous acid water (HOCL).

4. It can be used as toilet water or cleaning water.

5. It can be used in food service facilities or restaurants to remove odors and sterilize cutting boards and cooking utensils.

The sink should maintain a chlorine concentration of about $0.2 \mathrm{ppm}$, but chlorine ions are lost in tanks or pipelines, and some sink faucets generate scale, or bacteria. Fig. 6 shows a sterilizing hand washing table with a sterilizing water producing device attached.

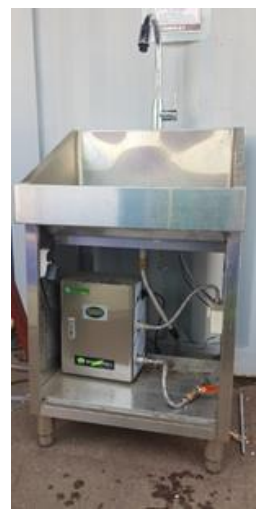

Fig. 6. Sanitizing hand washer.

This sterilized water also meets drinking water standards. Table V shows the drinking water test results of pure water measured by JK Life Science Laboratory.

TABLE V

DRINKING WATER TEST OF PURE WATER.

\begin{tabular}{|l|l|l|l|}
\hline Parameter & Result(mg/L) & \multicolumn{1}{|c|}{ Limit } & \multicolumn{1}{|c|}{ Mrthod } \\
\hline $\mathrm{Cl}$, total & 90.0 & 0.50 & EPA 300.0 \\
\hline $\mathrm{F}$, total & $\mathrm{ND}$ & 0.10 & EPA 300.0 \\
\hline $\mathrm{SO}_{4}{ }^{-2}$ & $\mathrm{ND}$ & 0.50 & EPA 300.0 \\
\hline $\mathrm{Ca}$, total & 70.0 & 0.10 & EPA 200.7 \\
\hline $\mathrm{Mg}$, total & 7.78 & 0.10 & EPA 200.7 \\
\hline $\mathrm{Fe}$, total & $\mathrm{ND}$ & 10.0 & EPA 200.7 \\
\hline $\mathrm{K}$, totla & $\mathrm{ND}$ & 0.10 & EPA 200.7 \\
\hline $\mathrm{Na}$, total & 28.4 & 0.50 & EPA 200.7 \\
\hline
\end{tabular}

\section{CONCLUSION}

An electrolysis device that uses a CNT composite as a cathode, that is, a device for producing sterilized water, was manufactured to investigate the sterilization ability and potable water potential. It satisfies the drinking water standard and showed good results in removing general bacteria and E. coli. This device provides sterilizing water suitable for medical use in dentistry and for hand washing required as COVID19 is prolonged. It expands to effectively remove pesticides from fruits, etc., and can effectively remove bacteria by washing pork. It can effectively purify the wastewater from the laver processing plant. In addition, the water in the swimming pool can be sterilized and purified without using chemicals. You can wash your car at a car wash without using detergent. In this case, environmental conservation and economic costs can be reduced by not generating wastewater that causes environmental pollution.

\section{REFERENCES}

[1] https://youtu.be/r6BkJVWqngA

[2] Sundo Corporation. 2019. Supply and recovery of nutrient solution for hydroponic cultivation using hydrogen water supply device and hydrogen water. Korean Patent No. 10-0985920

[3] Bon-Min Koo. 2012. Hydrogen water generator. Korean Patent No. 101190779

[4] Hiroshima Kasei Kabushi Kaisha, Kabushi Kaisha Minus 600 millivolts. 2019. Hydrogen water production device. Korean Patent No. 20-0490038

[5] Mi-Jung Park. 2018. Growth Inhibitory Effect of Hydrolyzed Hydrogen Water on Candida albicans[dissertation]. [Kyungpook National University (MA)], Kyungpook National University.

[6] Mi-Hee Shin, Rae-Eun Park, Hideo Nojima, Hyung-Chel Kim, YeonKyung Kim, Jin-Ho Chung. 2013. Atomic Hydrogen Surrounded by Water Molecules, $\mathrm{H}\left(\mathrm{H}_{2} \mathrm{O}\right) \mathrm{m}$, Modulates Basal and UV-Induced Gene Expressions in Human Skin In Vivo. PLOS ONE | www.plosone.org. 8(4)

[7] Eun-Joo Kim. 2017. Effect of intake of hydrogen rich water on the skin condition of the middle-aged women[dissertation]. [Konkuk University (PA)], Konkuk University.

[8] Ja-Yoon Ku. 2017. Effects of Combination of Korean Red Gnseng Extract and Hydrogen-rich Water on Spermatogenesis and Sperm Motility in the Mouse Model[dissertation]. [Pusan National University (PA)], Pusan National University.

[9] Jong-Kyung Kim. 2010. Effects of Highly Active Hydrogen Drinking on Muscle Fatigue in College Basketball Players[dissertation]. [Kyunghee University (MA)], Kyunghee University. 2010.

[10] Jun YE, Yuping LI, Takeki HAMASAKI, Noboru NAKAMICHI, Takaaki KOMATSU,Taichi KASHIWAGI, et al. 2008. Inhibitory Effect of Electrolyzed Reduced Water on Tumor Angiogenesis. Biol. Pharm. Bull. 31(1), 19-26

[11] Kokichi Hanaoka, Dongxu Sunc, Richard Lawrencec, Yoshinori Kamitanib, Gabriel Fernandesc. 2004. The mechanism of the enhanced antioxidant effects against superoxide anion radicals of reduced water produced by Electrolysis. Biophysical Chemistry. 107, 71-82

[12] Mi-Ja Kim, Kyung-Hee Jung, Yoon-Kyung Uhm, Kang-Hyun Leem, Hye-Kyung Kim. 2007. Preservative Effect of Electrolyzed Reduced Water on Pancreatic b - Cell Mass in Diabetic db/db Mice. Biol. Pharm. Bull. 30(2), $234-236$ 


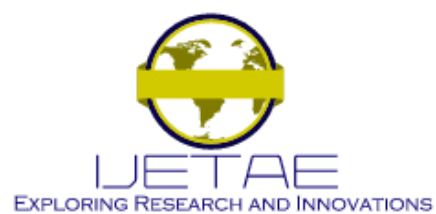

International Journal of Emerging Technology and Advanced Engineering Website: www.ijetae.com (ISSN 2250-2459, ISO 9001:2008 Certified Journal, Volume 11, Issue 03, March 2021)

[13] Ohsawa I, Ishikawa M, Takahashi K, Watanabe M, Nishimaki K, Yamagata K, Katsura K, Katayama Y, Asoh S, Ohta S., 2007. Hydrogen acts as a therapeutic antioxidant by selectively reducing cytotoxic oxygen radicals, Nat Med. 13(6), 688-94.

[14] Cai J, Kang Z, Liu WW, Luo X, Qiang S, Zhang JH, Ohta S, Sun X, Xu W, Tao H, Li R.,2008. Hydrogen therapy reduces apoptosis in neonatal hypoxia-ischemia rat model, Neurosci Lett. 441(2):167-72.

[15] Jon S.Cardinal, JianghuaZhan, YinnaWang, RyujiroSugimoto, AllanTsung, Kenneth R.McCurry, et. al., 2010. Oral hydrogen water prevents chronic allograft nephropathy in rats. Kidney International. 77(2), 101-109

[16] Nancy (Andrews) Dewhirst. 2015. Essential basis for checking dental unit water pipes, DENTISTRY, 257, 40-42, www.kdmnews.com

[17] Hye-Young Yoon and Si-Young Lee. 2015. The Microbial Contamination and Effective Control Method of Dental Unit Water System, J Dent Hyg Sci. 15(4), 383-392 